\title{
LA LEY Y LA AUTORIZACION DE LAS CORTES A LOS TRATADOS INTERNACIONALES
}

\author{
POR \\ FERNANDO SANTAOLALLA LOPEZ \\ Doctor en Derecho \\ Letrado de las Cortes
}

\begin{abstract}
SUMARIO
I. El PROBlema DE LA FORMA JURÍdica de LAS DECISIONES PARLAMENTARIAS: A) Introducción. B) Las decisiones singulares del poder legislativo. C) Las decisiones singulares del poder legislativo en la Constitución española. D) La cuestión en la doctrina. E) Nuestra consideración del problema.II. Forma dE LA AUTORIZACIÓN DE las CORTES para La RATIFICACIÓN DE LOS TRATADOS Y CONVENIOS INTERNACIONALES: A) Planteamiento del problema. B) Vicisitudes en la tramitación parlamentaria del artículo 94.1 de la Constitución. C) El mandato del artículo 63.2. D) Antecedentes constitucionales españoles y práctica actual sobre la autorización para ratificar. E) Precedentes extranjeros. F) Razones de fondo que aconsejan la forma legislativa para estas autorizaciones de las Cortes. G) La forma de ley es una consecuencia del Estado de Derecho. $\mathrm{H}$ ) La forma de ley y la impugnación de los tratados internacionales ante el Tribunal Constitucional. I) El procedimiento parlamentario y la constancia oficial de la autorización de las Cortes reclaman la forma legislativa. J) La forma de ley no afecta a la entrada en vigor del tratado. K) Otros argumentos en favor de la forma de ley.
\end{abstract}

\section{EL PROBLEMA DE LA FORMA JURIDICA DE LAS DECISIONES PARLAMENTARIAS}

\section{A) Introducción}

Desde los inicios del Estado constitucional, el principio de la división de poderes ha determinado que el Parlamento sea considerado como el poder legislativo o el Legislativo sin más. Concretamente, durante el siglo XIX, el hecho de que la actividad legislativa fuese la más desarrollada por las Cámaras determinó una inversión de aquellos términos, en el sentido de que la expresión poder legislativo pasó a sustantivarse, arrinconando en muchas ocasiones a las otras denominaciones de esta institución estatal, de tal forma que 
hubiera podido pensarse que el Parlamento no desarrollaba otra actividad que la puramente normativa ${ }^{1}$.

Sin embargo, es obvio que junto a esta actividad primordial coexistían otras funciones desplegadas por el Parlamento: la función presupuestaria, la función de control del Gobierno, la función jurisdiccional, etc.

No nos corresponde estudiar en este lugar ni el concepto de cada una de estas funciones ni tampoco su diferenciación frente a la función legislativa. Pero sí interesa recordar que estas funciones no son excluyentes entre sí, sino que, al contrario, pueden producirse con la realización de un mismo acto ${ }^{2}$. Así, la función presupuestaria consiste en la aprobación del plan de ingresos y gastos del Estado para un período determinado. Al mismo tiempo, la aprobación de los Presupuestos supone el ejercicio de la función legislativa en cuanto que esa aprobación se realiza normalmente por ley. Lo que ocurre en estos casos es que se enfoca una misma actividad desde un doble punto de vista: material y formal. En el ejemplo dado, y desde un punto de vista material, o sustancial si se quiere, estamos ante un acto de la función presupuestaria. Si en el mismo caso se aplica un prisma formal, nos encontramos con la función legislativa ${ }^{3}$. Lo mismo ocurre con los actos parlamentarios de control del Gobierno que pueden presentarse con forma de ley.

\section{B) Las decisiones singulares del poder legislativo}

Una vez hecha esta somera introducción, procede enfrentarse con el tema central de nuestro estudio, consistente en determinar en qué casos las decisiones parlamentarias deben revestirse con el ropaje de la ley. Parece fuera de toda duda que las leyes materiales del Parlamento deben ser también leyes formales. Las normas que procedan de esta institución, y caracterizadas por las notas de abstracción, generalidad y aplicación repetitiva (típicas de las normas en sentido material), deben figurar como leyes formales. Pero existen también decisiones de las Cámaras que, por su carácter singular o único, no pueden catalogarse como normas o leyes en sentido material y, sin embargo, se presentan con forma de ley. Se trata de las llamadas, por la doctrina clásica, leyes meramente formales, leyes cuyo contenido no es una norma en sentido

'Véase, sobre este punto, M. García Pelayo, Las transformaciones del Estado contemporáneo, Civitas, Madrid, 1977.

${ }^{2}$ Como dice Jellinek las diversas funciones materiales tienden a mostrarse en órganos peculiares. Pero la división de funciones, aun en los países donde está reconocida la separación de poderes, no es posible realizarla de una manera completa. Y, así como la Administración Pública asume funciones materiales diversas, también los órganos legislativos toman parte en ciertos actos administrativos cuya ordenación o autorización sólo puede hacerse por ley, así como en ciertos actos judiciales. Véase Teoría general del Estado, Buenos Aires, 1973 , págs. 460 y sigs.

${ }^{3}$ Este desdoblamiento de puntos de vista permite a Prelot calificar a la Ley de Presupuestos como un acto de control del Gobierno. Véase Institutions Politiques et Droit Constitutionnel, 6. edición, Dalloz, 1972. Por su parte, Mortati califica a la Ley de Presupuestos como un acto de la función de dirección política del Parlamento. Véase Istituzioni di Diritto Pubblico II, Padua, 1976, págs. 670 y sigs. 
estricto. Tal es el caso de la ley aprobatoria de los Presupuestos o de la que autoriza la proclamación del estado de sitio, etc. Ahora bien, ¿ pueden existir otras decisiones singulares de los Parlamentos que se produzcan sin forma de ley? En caso afirmativo, ¿en qué casos y por qué razones deben presentarse unas decisiones con forma legislativa y otras sin ella? ¿Cuáles son los distintos efectos que se derivan de cada una de estas posibilidades?

\section{C) Las decisiones singulares del poder legislativo en la Constitución española}

Si echamos una ojeada a la Constitución española de 1978 comprobaremos una serie de decisiones singulares de las Cortes en que la propia Constitución exige expresamente que se hagan por ley ${ }^{4}$. Así, la aceptación de las abdicaciones y renuncias a reinar y la resolución de cualquier duda en el orden de sucesión a la Corona (art. 57.5); la autorización para refundir textos. legales (art. 82.2); la autorización para celebrar tratados de cesión de competencias constitucionales a organizaciones internacionales (art. 93); la autorización para la Constitución de una Comunidad Autónoma cuando su ámbito no supere el de una provincia y la sustitución de la iniciativa de las Corporaciones Locales a que se refiere el artículo 143.2 [art. 144, apart. a) y c), respectivamente]; la ley de Presupuestos Generales del Estado (art. 134.4), y la autorización por el Gobierno para emitir Deuda Pública o contraer crédito (art. 135.1). En estos ejemplos no nos encontramos con verdaderas leyes materiales, en el sentido de normas generales, abstractas, de aplicación reiterada, etc., sino ante decisiones únicas: resolución de dudas, autorizaciones para que el Gobierno pueda hacer algo, etc. Lo que debe recalcarse ahora es que, a pesar de este carácter singular, todas ellas deben adoptarse con forma de ley.

Frente a esta serie de decisiones con ropaje legislativo, hay otras decisiones de las Cortes respecto de las cuales la Constitución calla sobre la forma en que deben presentarse. Nuestro primer texto legal no nos dice si estos acuerdos deben tener forma de ley u otra distinta. Así, y sin ánimo de ser exhaustivos, pueden relacionarse los siguientes casos: determinación para la sucesión de la Corona cuando se hayan extinguido todas las líneas llamadas en Derecho (art. 57.3); prohibición para contraer matrimonio a las personas con derecho a sucesión en el trono (art. 57.4); autorización para declarar la guerra y hacer la paz (art. 63.3); autorización para obligarse por medio de tratados o convenios internacionales (art. 94.1); autorización para que las Comunidades Autónomas puedan establecer acuerdos de cooperación distintos de los de gestión y prestación de servicios propios de las mismas (art. 145.2); distribu-

\footnotetext{
4 Nos refetimos a todos los casos en que estos acuerdos deben manifestarse por ley, independientemente de que ésta sea orgánica u ordinaria. No hay una diferencia de naturaleza entre ambas categorías de leyes, sino sólo de competencia y de procedimiento. Aunque se admitiese una superioridad jerárquica de las leyes orgánicas sobre las ordinarias, no se podría afirmar una diferencia cualitativa entre ambas. Por eso, no hay tampoco una distinción sustancial entre las decisiones singulares adoptadas por ley ordinaria y aquellas otras que lo hacen con ley orgánica.
} 
ción de los recursos del Fondo de compensación interterritorial con destino a gastos de inversión (art. 158.2). Ante estos supuestos cabe preguntarse por la forma con que deberán producirse. El hecho de que la Constitución exija en unos casos la forma de ley y en otros no ¿es suficiente para excluirla en estos últimos?, o ¿más bien deberá aplicarse por analogía la forma de ley en todos los supuestos? En caso contrario, ¿cabe otra forma distinta para los acuerdos? ${ }^{5}$.

Los mismos interrogantes surgen ante una serie de decisiones unicamerales de importancia jurídico-política indudable. Tal es el caso de la autorización del Congreso para la convocatoria de referéndum (art. 92.2); la decisión de la misma Cámara en orden a la convalidación o derogación de los decretosleyes dictados por el Gobierno (art. 86.2); la autorización del Congreso para prorrogar los estados de alarma y para decretar los estados de excepción (artículo 116, apart. 2 y 3, respectivamente); la declaración del estado de sitio (art. 116.4); la aprobación del Senado para que el Gobierno pueda adoptar medidas para obligar a una Comunidad Autónoma al cumplimiento forzoso de sus obligaciones constitucionales y legales (art. 155.1).

\section{D) La cuestión en la doctrina}

Es escasa la literatura jurídico-política que ha tratado de estos extremos, o al menos la que nos es conocida a nosotros. Duguit distinguía, junto a las leyes, la existencia de resoluciones del poder legislativo, indicando que éstas eran las resultantes del voto de una sola Cámara y que carecían del valor de las primeras ${ }^{6}$.

Pero quien, quizá, ha tratado con más detenimiento esta cuestión ha sido Laband ${ }^{7}$. En íntima conexión con su concepción formal de la ley, señaló cómo ésta se aplicaba no sólo a las decisiones del Parlamento para el establecimiento de reglas de Derecho, sino también a asuntos de carácter administrativo en el sentido más amplio del término: presupuesto del Imperio, concertación de empréstitos, etc. Pero, junto a la forma de ley, existe también - decía Laband - la forma del consentimiento del Reichstag, existiendo entre ambas una diferencia fundamental: sin la voluntad aprobatotia del Reichstag no puede haber ley en modo alguno, dado que aquélla es conditio sine qua non para esta última.

En cambio, el consentimiento del Reichstag se refiere a actos gubernamentales, a actos cuyo titular no es el Parlamento. Por eso la ausencia de dicho consentimiento del Reichstag no determina sin más la nulidad del acto correspondiente. Para ser válidos, desde el punto de vista formal, estos actos no

${ }^{5}$ Nuestro propósito inicial era abordar el estudio de la mayoría de estos casos. Sin embargo, la extensión que ello hubiese comportado nos ha aconsejado limitarnos de momento al caso de la autorización de las Cortes para que el Estado pueda obligarse por tratados internacionales, dejando para el futuro el estudio gradual de los otros supuestos.

${ }^{6}$ Véase Traité de Droit Constitutionnel IV, París, 1924, págs. 302 y sigs.

${ }^{7}$ Véase Le Droit Public de l'Empire Allemand I, París, 1900, págs. 447 y sigs. 
necesitan de la aprobación de la Cámara. El consentimiento de ésta es algo perfectamente separado e independiente de la declaración de voluntad del Gobierno, no forma parte de ella. Tal era el caso de ciertas ordenanzas, cuya publicación estaba confiada a órganos del Imperio, pero con la obligación de tener que ser presentadas ante el Reichstag, de tal modo que perdían su vigencia o debían ser retiradas si la Cámara negaba su consentimiento. Al ser estas ordenanzas actos gubernamentales - recordaba Laband-; su aprobación por el Reichstag no determina su transformación en ley, sino que siguen siendo actos gubernamentales.

También Carré de Malberg advirtió la existencia, junto a las leyes, de otras decisiones del Parlamento sin esta forma: la aprobación o ratificación de decisiones singulares ${ }^{8}$. No obstante, este autor reconocía que el Parlamento puede también adoptar decisiones singulares empleando la forma legislativa, lo que es exigido en diversos casos: por ejemplo, la declaración del estado de sitio, la declaración de utilidad pública de ciertas obras, etc. El empleo de una y otra vía, simple resolución o ley, lleva aparejado efectos bien distintos. Cuando el poder legislativo emplea la simple resolución autorizando un acto, éste continúa siendo un acto puramente administrativo. Por el contrario, cuando el Parlamento decide mediante una ley, se apropia del acto y lo transforma en un acto legislativo. El acto en cuestión pasa a ser un elemento del orden legislativo superior del Estado. Además, junto a las leyes que contienen una decisión singular (ejemplos mencionados), existen otras que se limitan a autorizar actos de la competencia del poder ejecutivo. Tal es el caso de las leyes autorizando al Gobierno para ratificar un tratado internacional, o de las que autorizan ciertos actos que incumben a las autoridades locales. Estas leyes, a diferencia de las anteriores, no realizan por sí mismas el acto a que se refieren: se limitan a autorizarlo. El acto realizado en virtud de la autorización es un acto administrativo. En este sentido ocurre'lo mismo que si se hubiese empleado una simple resolución. Pero, cuando la autorización se confiere en forma de ley, no se pretende sólo que el acto administrativo cuente con la aprobación del Parlamento, sino que sea un acto dictado «en ejecución de una ley, es decir, en virtud de una prescripción superior, constituyendo para la autoridad administrativa un principio determinante de actividad». De esta forma, dice Carré de Malberg, «la exigencia de la forma de ley responde a la concepción constitucional moderna, según la cual esta forma es la condición misma de la ley, considerada como expresión de la voluntad estatal más alta». (Debe recordarse que para este autor la ley no se caracteriza por su contenido, que puede ser general o singular, sino por su especial fuerza de obligar que se impone a todos los órganos del Estado) ${ }^{9}$.

Más modernamente, y también en Francia, Boudet se ha planteado el tema de la distinción entre ley y resolución parlamentaria y los distintos efectos

${ }^{8}$ Véase Contribution a la Théorie Générale de l'Etat I, París, 1920, págs. 367 y sigs. Ejemplos de estas resoluciones podrían ser el consentimiento para que el presidente de la República pudiese declarar la guerra (art. 9, ley 16 de julio de 1875) y la declaración de las Cámaras de haber lugar a la reforma constitucional (art. 8, ley 25 de febrero de 1875).

${ }^{9}$ Véase $o b$. cit., págs. 328 , y 370 y sigs. EI subrayado es nuestro. 
jurídicos de estos actos ${ }^{10}$. Tras recordar que la noción francesa de ley es puramente formal, en el sentido de que le es indiferente que su contenido sea general o particular, señala que la resolución es una moción votada por una sola de las dos Cámaras y carente de promulgación (y siempre que no sea una simple medida de aplicación del Reglamento interno de éstas). Estas resoluciones pueden tener un alcance interno (por ejemplo, aprobación de su Reglamento) o externo (así, las que tiendan a regular las relaciones entre las Cámaras o las que invitan al Gobierno a presentar un determinado proyecto de ley). En relación a estas últimas, señala Boudet que el Parlamento no puede utilizarlas para imponer su voluntad a otros órganos, a diferencia de lo que ocurre con la ley, a través de la cual pueden adoptarse decisiones generales vinculantes. La resolución de objeto externo no es más que una institución indicativa, sin fuetza de obligar, salvo en los concretos casos en que supone el ejercicio de una competencia constitucional. Así, cuando la resolución consiste en un voto de confianza o en una moción de censura, la Asamblea Nacional decide el inicio o el fin de los Gobiernos ${ }^{11}$. Sólo en estos casos especiales $\mathrm{y}$ en las resoluciones internas tienen fuerza de obligar. En los demás casos no tienen otro valor que el político de sugerir o indicar.

\section{E) Nuestra consideración del problema}

Resumiendo las teorías expuestas puede sostenerse que hay actos o decisiones gubernamentales que, por determinarlo así la Constitución, están sujetos a la aprobación parlamentaria. En unos casos esta autorización o aprobación puede conferirse mediante simple resolución parlamentaria, entendiendo la resolución parlamentaria en sentido genérico, esto es, como decisión no cubierta con la forma de ley ${ }^{12}$. En otros casos, el empleo de la forma de ley es preceptivo. Tanto en uno como en otro supuesto, los actos o decisiones sometidos a la autorización del poder legislativo siguen siendo actos del Gobierno. Pero la autorización o aprobación que se confiere por ley adquiere la vinculatoriedad y la fuerza de obligar general propias de todas las leyes. Así, por ejemplo, podrá ser sometida al control de constitucionalidad de las leyes o podrá servir de parámetro de referencia para un eventual recurso contenciosoadministrativo. En cambio, cuando la autorización se confiere mediante una simple resolución parlamentaria, no goza de la fuerza general de obligar, propia de la ley.

La resolución parlamentaria no tiene más obligatoriedad que la que la

${ }^{10}$ Véase La force juridique des résolutions parlementaires, en Revue du Droit Public et de la Science Politique, 1958, págs. 273 y sigs.

11 Téngase en cuenta que el trabajo referido está escrito a la vista del sistema constitucional de la IV República.

${ }^{12}$ En el presente estudio se usa la expresión resolución o resolución parlamentaria en sentido genérico. Téngase en cuenta que los Reglamentos y la práctica parlamentaria emplean distintas denominaciones (mociones, resoluciones, órdenes del día) para referirse a una misma categoría de actos. Véase Nocilla, voz Mozione, en Enciclopedia del Diritto, XXVII, Milán, 1977, pág. 343. 
Constitución haya querido darla en cada caso, y sólo vincula a los concretos órganos a los que vaya dirigida. En consecuencia, la Cámara, o Cámaras interesadas, no pueden pretender vincular a todos los órganos del Estado y a los ciudadanos a través de simples resoluciones.

La Ley es el acto soberano por el que se expresa la voluntad parlamentaria. Como ha escrito Fabre, de este principio se derivan los siguientes efectos ${ }^{13}$ : por su contenido, la ley es un acto indeterminado, en cuanto puede contener reglas generales o decisiones individuales; es un acto indefinido, por cuanto puede intervenir en cualquier materia, salvo en los sistemas donde se establece una reserva reglamentaria, $y$, finalmente, es un acto supremo por cuanto puede modificar o derogar cualquier disposición inferior a la Constitución. En el mismo sentido, Modugno ha escrito que la legislación puede asumir cualquier contenido que no contradiga la Constitución y, más particularmente, un contenido particular y concreto, lo que, a su vez, determina una prevalencia de los factores formales sobre los materiales para la determinación de la noción de ley ${ }^{14}$.

Consecuentemente, puede afirmarse que la ley es la forma normal de expresión externa del poder Legislativo. Como principio puede sostenerse que, para que sus decisiones puedan tener carácter vinculante general, deberán presentarse como ley, pues sólo esta forma asegura que su fuerza de obligar se extienda a todos los ciudadanos y órganos del Estado ${ }^{15}$.

${ }^{13}$ Véase La loi expression de la souveranité, en Revue du. Droit Publique et de la Science Politique, núm. 2, 1979, págs. 341 y sigs.

${ }^{14}$ Véase Legge in generale, en Enciclopedia del Diritto, XXIII, Milán, 1973, págs. 884 y sigs.', especialmente págs. 888 y sigs. Un interesante intento superador de la distinción entre ley formal y ley material se encuentra en C. Starck, El concepto de ley en la Constitución alemana, CEC, Madrid, 1979. Para Starck toda ley supone un precepto general e importante. Por lo general, el principio de universalidad que debe respetar toda ley determina que ésta sea general por su contenido. Pero, también hay casos de leyes singulares, porque su objeto no es regulable con carácter general. Por su importancia estas regulaciones o preceptos individuales se someten también al procedimiento legislativo y han de respetar los principios de libertad e igualdad. Ejemplo de estas leyes singulares son la de presupuesto y la de autorización de tratados internacionales. Por tanto, aun admitiendo que estas leyes implican preceptos y no actos materialmente administrativos, llega este autor a la conclusión de la variedad de contenidos de la ley.

${ }^{15}$ En España, Gallego Anabitarte ha intentado construir una concepción material de la ley, criticando la tradicional concepción formal y orgánica. Este autor sostiene (Ley y Reglamento en el Derecbo público occidental, I. E. A., Madrid, 1971) que en la Constitución de 1812 y en el Reglamento de las Cortes de 1813 se diferenciaba entre la ley y el decreto de Cortes, siendo la ley un acto de las Cortes y del Rey (dada la sanción de éste último), mientras que los decretos quedaban reservados exclusivamente a las Cortes. Las leyes, según este autor, suponían regulaciones o mandatos de importancia, sancionados y promulgados por el Rey mientras que los decretos eran resoluciones importantes o trascendentes, de exclusiva competencia de las Cortes, por lo que estaban excluidos de la sanción regia.

Si bien no es éste el momento de abordar con el debido detenimiento la cuestión, podemos resumir nuestra postura señalando que no pueden extraerse las conclusiones que Gallego Anabitarte obtiene de la expresión decreto de las Cortes, contenida en los artículos 108 y sigs. de su Reglamento de 1813. En este sentido, debe señalarse el alcance totalmente genérico e impreciso con que se usa esta expresión por el Derecho de la época: las expresiones decreto y decretar equivalen a las de decisión y decidir y no a una forma concreta de acto. Así, en el período 1810-1812 no se produjeron por parte de las Cortes 


\section{FORMA DE LA AUTORIZACION DE LAS CORTES PARA LA RATIFICACION DE LOS TRATADOS Y CONVENIOS INTERNACIONALES}

\section{A) Planteamiento del problema}

Una vez examinadas las distintas consecuencias que se derivan de las autorizaciones del Parlamento, según se adopten con o sin forma legislativa, procede enfrentarse con el problema de optar por una $\mathbf{u}$ otra vía en concretos supuestos de nuestra Constitución.

Uno de éstos es la autorización de las Cortes para que el Estado pueda obligarse por medio de tratados o convenios internacionales. Aunque sobre este punto ya hemos manifestado alguna opinión ${ }^{16}$, entendemos que no es ocioso volver sobre el mismo para examinarlo a la luz de las anteriores consideraciones y con mayor detenimiento.

Dos casos contempla en este sentido nuestra Constitución. El primero de ellos, previsto en el artículo 93, no plantea ningún problema en cuanto expresamente se requiere que la autorización sea conferida por ley orgánica ${ }^{17}$. Dice así el artículo mencionado:

«Mediante ley orgánica se podrá autorizar la celebración de tratados por los que se atribuya a una organización o institución internacional el ejercicio de competencias derivadas de la Constitución. Corresponde a las Cortes Generales o al Gobierno, según los casos, la garantía del cumplimiento de estos tratados y de las resoluciones emanadas de los organismos internacionales o supranacionales titulares de la cesión.»

La claridad del precepto, a los fines que aquí interesan, nos exime de otro comentario que el de recordar la exigencia de la forma legislativa para la autorización conferida por las Cámaras al Gobierno.

Por su parte, el artículo 94.1 dispone:

«La prestación del consentimiento del Estado para obligarse por medio de tratados o convenios requerirá la previa autorización de las

más que Decretos y Ordenes, excepción hecha de la Constitución, según consta en la Colección de los Decretos y Ordenes que ban expedido las Cortes Generales y Extraordinarias, Madrid, 1820. Estos Decretos y Ordenes encerraban decisiones singulares o auténticas normas generales de muy variable relevancia. En la Colección de leyes, decretos y declaraciones de las Cortes, Madrid, 1838, se recogen disposiciones como Decretos de las Cortes que al mismo tiempo aparecen sancionadas por la Reina y calificadas como leyes. Por eso, la imprecisión de esta primera época en el empleo de los términos ley y decreto no vale, por sí sola al menos, para criticar la concepción orgánica o subjetiva de las normas jurídicas.

${ }_{16}$ Véase Los tratados como fuente del Derecbo en la Constitución, publicado en La Constitución y las fuentes del Derecbo III, Instituto de Estudios Fiscales, Madrid, 1979, y en R. A. P., núm. 90, septiembre-diciembre 1979.

${ }_{17}$ Ya hemos dicho anteriormente que el empleo de ley orgánica o la de ordinaria no afecta para nada a la cuestión aquí estudiada, habida cuenta de la indiferencia sustancial que existe entre ambas modalidades. 
Cortes Generales, en los siguientes casos: a) Tratados de carácter político; $b$ ) Tratados o convenios de carácter militar; c) Tratados o convenios que afecten a la integridad territorial del Estado o a los derechos y deberes fundamentales establecidos en el título I; $d$ ) Tratados o convenios que impliquen obligaciones financieras para la Hacienda Pública; e) Tratados o convenios que supongan modificación o derogación de alguna ley o exijan medidas legislativas para su ejecución.»

A diferencia del precepto anterior, que se refiere al supuesto especial de los tratados de transferencia de competencias constitucionales, el artículo 94.1 contempla el supuesto general de los tratados que requieren previa autorización de las Cortes para su ratificación ${ }^{18}$. La inmensa mayoría de los convenios internacionales que deban remitirse a las Cortes - que abarca un número amplísimo de ellos, dada la amplitud del precepto- lo harán en virtud de lo establecido en este artículo.

En el mismo no se menciona cuál es la forma en que las Cortes deberán conferir, en su caso, la autorización para vincular al Estado por un convenio internacional. Surge entonces la duda de si, por aplicación analógica de lo establecido en el artículo 93, deberá emplearse la forma de ley o si, por el contrario, y al amparo de la regla ubi lex voluit dixit, deberá evitarse ésta y emplearse otra distinta.

Las páginas que continúan pretenden demostrar la necesidad de que la autorización de las Cortes, cuando ésta deba producirse, se adopte con forma de ley. Desde este momento conviene dejar claro que esta ley no es un caso de las llamadas leyes de transformación, o de ejecución de las normas internacionales en normas internas, lo que supondría la aceptación de una concepción dualista de las relaciones entre el ordenamiento interno y el internacional. Por el contrario, no es más que una manifestación de las leyes formales que, en lugar de contener reglas jurídicas en sentido estricto, comportan una decisión singular, en este caso una autorización al ejecutivo para poder ratificar un tratado.

\section{B) Vicisitudes en la tramitación parlamentaria del artículo 94.1 de la Constitución}

Para poder conocer si hubo una verdadera intención del constituyente para excluir la forma legislativa de estas autorizaciones es preciso hacer. un breve repaso a la historia parlamentaria de este artículo.

En el Anteproyecto de Constitución, publicado en el BOC, núm. 44, de 5 de enero de 1978, esta materia era regulada en el artículo 55.2, que disponía lo siguiente:

18 En el presente estudio empleamos el término «ratificación» en sentido genérico, comprensivo de las distintas modalidades a través de las que el Estado puede obligarse internacionalmente. 
«El Rey autoriza la celebración de los tratados internacionales y, en su caso, los ratifica. Sin embargo, la conclusión de tratados que afecten a materia competencia de las Cortes Generales deberá ser previamente autorizada mediante ley.»

Por tanto, el primer antecedente parlamentario de nuestro texto constitucional era inequívoco en exigir una ley para la autorización de la conclusión de convenios internacionales.

Fueron diversas las enmiendas presentadas a este artículo (núm. 272 de Socialistas de Catalunya, núm. 145 de Minoría Catalana, núm. 624 del Grupo Vasco, núm. 697 del Grupo Comunista y 779 del Grupo UCD). La Ponencia, en su Informe ( $B O C$, núm. 82, de 17 de abril de 1978), dijo aceptar en lo fundamental lo interesado en las enmiendas de la Minoría Catalana y del Grupo Vasco, las cuales mantenían la exigencia de la ley para estas autorizaciones. Sin embargo, aunque no lo expresase, fue evidente la aceptación de la enmienda 272 del Grupo Socialistes de Catalunya ${ }^{19}$, dada su semejanza con el texto resultante. En esta última enmienda no constaba la referencia a la ley, pero ello se hacía «en consonancia con el voto particular de supresión del artículo 72 del Anteproyecto, presentado por el Grupo Socialista del Congreso, y al que este Grupo se suma» ${ }^{20}$. Este artículo 72 es el que establecía la reserva de ley de ciertas materias. La postura de los Grupos Socialistas fue contraria a que se limitase constitucionalmente el ámbito de la ley. Esta debió ser la razón que impulsó a omitir la mención de la ley para la autorización para obligarse mediante tratados, tal vez con el propósito de eliminar toda referencia que pudiese significar una limitación del dominio de la ley. En definitiva, no se debió perseguir que estas autorizaciones fuesen conferidas en forma distinta a la ley, sino que la cuestión no prejuzgase el ámbito de la ley en nuestro ordenamiento.

Esta impresión resulta corroborada por el hecho de que fue el Grupo Socialista del Senado - del mismo partido político que el Grupo Socialista del Congreso- quien presentó en la Cámara Alta la enmienda número 1.069, destinada a reintroducir la mención «mediante ley» como forma de la autorización de las Cortes para la ratificación de un acuerdo internacional. Con ello se debió querer subsanar el error técnico padecido en el Congreso: una vez suprimido el antiguo artículo 72 del Anteproyecto ( $B O C$ de 5 de enero de 1978), que limitaba las cuestiones que podían regularse por ley, debió parecer innecesaria la omisión de la referencia a la ley como forma de expresión del consentimiento de las Cámaras, a la par que perjudicial desde un punto de vista técnico, pues planteaba el problema de determinar en qué forma debía conferirse la autorización parlamentaria. En definitiva, se debió presentir el problema interpretativo que ahora nos toca afrontar. La reaparición de la mención de la ley no presentaba ya el peligro de que se instrumentase para defender un ámbito restringido de la misma en nuestro Derecho.

Al defender la enmienda referida, el senador Sainz de Varanda señaló: «Creemos que es la forma normal que revista la forma de ley la autorización

19. Esta situación debió producirse por un error en la redacción material del informe.

${ }^{20} \mathrm{El}$ texto entrecomillado formaba parte de la justificación de la enmienda. 
a recibir por el Estado para suscribir los tratados» ${ }^{21}$. La enmienda fue apoyada expresamente por los portavoces de la mayoría de los Grupos parlamentarios. Ásí, los senadores Sánchez Agesta, Martín-Retortillo Baquer ${ }^{22}$ y Ballarín Marcial ${ }^{23}$. No obstante lo anterior, en el último momento se señaló que, si bien la enmienda socialista era acertada desde un punto de vista formal, podía crear confusión con el artículo 74.2 de la Constitución, que contiene un procedimiento especial con intervención de una Comisión mixta Congreso-Senado ${ }^{24}$, «porque las leyes no exigen dichas Comisiones mixtas». Esta indicación fue aceptada, suprimiéndose la mención «mediante ley». En este resultado influyó, sin duda, la premura con que debió debatirse el texto, lo que dificultó que estas y otras cuestiones fuesen abordadas con la reflexión deseable.

Parece indudable, a nuestro juicio, que lo que hace el artículo 74.2 es establecer un procedimiento especial en que se da una mayor consistencia a la participación del Senado en la adopción de decisiones de la competencia de las Cortes (iniciación ante el mismo en dos de los tres casos previstos e intervención de una Comisión mixta). La ratio de este precepto no es configurar una forma especial - distinta de la legislativa- para los acuerdos de las Cortes, sino establecer unos concretos supuestos en que no se aplica el procedimiento legislativo general del artículo 90 . En consecuencia; no es que el artículo 74.2 pretenda excluir la forma legislativa, sino que su verdadera finalidad es dotar al Senado de unas facultades de mayor peso que las que le corresponderían de aplicarse el procedimiento general.

Esta conclusión se ve respaldada pensando que si no existiese esta norma, los tres casos contemplados en la misma deberían regirse por el artículo 90. Por tanto, el artículo 74.2 no supone la introducción de una forma especial de los acuerdos de las Cortes, sino tan sólo una tramitación distinta y alternativa del procedimiento general del artículo $90^{25}$. A mayor abunda-

${ }^{21}$ Véase Diario de Sesiones del Senado, núm. 50, 1978, pág. 2328.

22 Ibíd., pág. 2330.

23. Este último senador expresó las siguientes consideraciones: «Nosotros aceptamos la enmienda del Grupo Parlamentario Socialista en cuanto que se requiere la Ley. Creo que con ello se resuelven muchos problemas. El Gobierno tendrá que enviar al Congreso el correspondiente proyecto acompañado del Informe y Memoria, conforme se dice. Las Cámaras podrán conocer, pues, con más fundamento las circunstancias que rodean el Tratado o convenio que haya que autorizar.» A pesar de lo indicado en estas palabras - por lo demás muy oportunas - debe indicarse que ni la enmienda ni el texto sometido a votación contenían referencia a Informes y Memorias. Concretamente, el texto sometido a votación decía lo siguiente: «1. La prestación del consentimiento del Estado para obligarse por medio de Tratados y convenios requerirá la previa autorización, mediante lej, de las Cortes Generales en los siguientes casos: ....».

${ }^{24} \mathrm{El}$ artículo se ha citado siguiendo la enumeración definitiva. Su apartado 2 dispone lo siguiente: «Las decisiones de las Cortes Generales previstas en los artículos 94.1, 145.2 y 158.2, se adoptarán por mayoría de cada una de las Cámaras. En el primer caso, el procedimiento se iniciará por el Congreso, y en los otros dos, por el Senado. En ambos casos si no bubiera acuerdo entre Senado y Congreso, se intentará obtener por una Comisión Mixta compuesta de igual número de diputados y senadores. La Comisión presentará un texto que será votado por ambas Cámaras. Si no se aprueba en la forma establecida, decidirá el Congreso por mayoría absoluta.»

${ }^{25}$ En el mismo sentido se manifiesta E. Recoder en Comentarios a la Constitución, de F. Garrido Falla y otros autores, Madrid, 1980, pág. 792. Este autor, tras señalar que este 
miento, debe recordarse que la intervención de comisiones mixtas ha sido la forma usual de dirimir las diferencias entre las Cámaras en relación a proyectos de ley, tanto en España (art. 10 de la Ley de 19 de julio de 1837 y artículo 4 de la Ley 1/1977, para la Reforma Política) como en otros países (Alemania, Francia, etc.), por lo que no puede esgrimirse en contra de la adopción de acuerdos con forma de ley.

En consecuencia, no cabe admitir en modo alguno que la autorización para ratificar tratados internacionales mediante ley de Cortes, haga incompatible la aplicación de lo ordenado en el artículo 74.2. Uno y otro aspecto son perfectamente armonizables. Por eso, la exclusión del inciso "mediante ley» del artículo 94.1, operada en la Comisión de Constitución del Senado, no debe llevar a la conclusión de que la Constitución prohíba su aplicación. La mencionada exclusión se efectuó en base a un error técnico fácilmente comprobable, por lo que no debe dársele ninguna relevancia especial a la hora de interpretar este artículo ${ }^{26}$. Las consideraciones que a continuación siguen pretenden respaldar la misma conclusión.

\section{C) El mandato del artículo 63.2}

Uno de los preceptos constitucionales concordantes con los antes referidos es el artículo 63.2, que dispone:

«Al Rey corresponde manifestar el consentimiento del Estado para obligarse internacionalmente por medio de tratados, de conformidad con la Constitución y las leyes.»

En su virtud, compete al Rey la función formal de vincular al Estado por medio de un tratado o convenio internacional, lo que normalmente se hará expidiendo los correspondientes instrumentos de ratificación o adhesión. Ahora bien, la norma transcrita determina que esta función se hará «de conformidad con la Constitución y las leyes». Aunque el precepto examinado adolece de cierta imprecisión ${ }^{27}$, no puede dejar de reconocerse que la referencia a la Constitución afecta sobre todo a lo ordenado en el capítulo III (de los tratados internacionales) del título III. Al mismo tiempo, la mención «de la conformidad con las leyes» debe entenderse referida a las leyes por las que las Cortes autorizan que el Estado se obligue por un convenio internacional. No puede entenderse esta expresión dirigida a una posible ley que discipline el procedimiento administrativo para la conclusión de estos tratados,

artículo fue introducido en el Senado, indica que la omisión de la referencia a las leyes en el artículo 74.2 se debió a un artilugio político a fin de evitar la sensación de que se alteraba el esquema general de predominio del Congreso. Por consiguiente, debió existir el convencimiento de que este artículo implica la aprobación de leyes.

${ }^{26}$ El artículo 3 del Código Civil da prioridad al espíritu y finalidad sobre los otros elementos interpretativos (gramatical, antecedentes históricos y legislativos, realidad social) de las normas jurídicas. Por esto y por las razones expresadas no puede recibir un valor especial lo acaecido en los debates de las Cámaras.

${ }_{27}$ Así lo ha reconocido O. Alzaga, La Constitución española de 1978, Madrid, 1979, página 418. 
esto es, a una ley que regule la materia hasta ahora contenida en el Decreto $801 / 1972$, de 24 de marzo. Si así fuera, la norma establecida habría usado un singular («de conformidad con la ley») en lugar del plural que aparece en el texto, el cual, por lo demás, guarda una perfecta simetría con el plural «tratados» de la primera parte de la norma, lo que parece indicar que debe haber una ley (de autorización) por cada tratado que se quiera concluir. Cuesta mucho trabajo concebir que la intención del constituyente, al redactar este inciso, fuese que la actual normativa administrativa contenida en el Decreto $801 / 1972$, se sustituyese por una norma de rango legal, pues esta cuestión no parece revestir la suficiente importancia como para ser objeto de una norma constitucional ${ }^{28}$. En el mismo sentido, la necesidad de que el procedimiento administrativo se regula por ley aparece ya recogida en el artículo 105.c) de la Constitución, por lo que es forzoso pensar que el inciso del artículo 63.2 se refiere a leyes distintas.

Al amparo de lo anterior puede sostenerse que la práctica seguida actualmente para la autorización de las Cortes, simple oficio de los presidentes de las Cámaras comunicando su autorización al Gobierno y omisión de la forma de ley, choca abiertamente con el sentido del artículo 63.2 de la Constitución ${ }^{29}$.

\section{D) Antecedentes constitucionales españoles y práctica actual sobre la autorización para ratificar}

El empleo de la ley en la autorización de las Cortes para la ratificación de tratados y convenios internacionales es casi constante en nuestro constitucionalismo.

Así, el artículo 46 de la Constitución de 1837 establecía:

«El Rey necesita estar autorizado por una ley especial: $1 .^{\circ}$ Para enajenar, ceder o permutar cualquiera parte del territorio español. 2. Para admitir tropas extranjeras en el reino. 3. Para ratificar los tratados de alianza ofensiva, los especiales de comercio y los que estipulen dar subsidios a alguna potencia extranjera. 4. Para abdicar la Corona en su inmediato sucesor.»

Como puede verse, este artículo comprende una serie de autorizaciones de las Cortes - entre las que se incluyen las referentes a la ratificación de tratados-, todas las cuales debían adoptarse mediante ley especial. Esta de-

${ }^{28}$ Esta interpretación no implica, evidentemente, que no se pueda regular por ley el procedimiento administrativo para la conclusión de Tratados, sino que no es esto lo exigido por el artículo 63 de la Constitución. Si, por el contrario, se afirmase que el sentido de este 'precepto constitucional es exigir la legalización de un procedimiento hasta ahora regulado reglamentariamente, habría que concluir que la aplicación del Decreto 801/1972 es anticonstitucional.

${ }^{29}$ Esta forma de comunicar los acuerdos viene determinada por el hecho de que el Gobierno remite los Tratados a las Cortes sin el acompañamiento del oportuno proyecto de ley de autorización. Desde este momento las Cámaras se ven muy condicionadas en torno a la forma que debe utilizarse. 
terminación se repetía en términos casi idénticos en los artículos 48 de la Constitución de 1845, 53 de la nonata a 1856, 74 de la Constitución de 1869 y 55 de la Constitución de 1876.

Respecto a la Constitución de 1931 debe señalarse que su artículo 76.e establecía la necesaria aprobación de las Cortes para la conclusión de una serie de tratados, pero sin expresar que ello tuviese que hacerse por ley. Sin embargo, esta exigencia figuraba de forma implícita en su artículo 66, párrafo 2:

«No serán objeto de este recurso (sometimiento a referéndum) la Constitución, las leyes complementarias de la misma, las de ratificación de convenios internacionales inscritos a la Sociedad de las Naciones, los estatutos regionales ni las leyes tributarias.»

Independientemente del error técnico de esta disposición ${ }^{30}$, que otorgaba a las Cortes la ratificación de los tratados cuando en realidad sólo se trataba de la autorización para ratificar, debe resaltarse su mención de las leyes - y no de otra forma - como acto a través del cual el Parlamento ejercía sus facultades autorizadoras en la materia citada. A mayor abundamiento, la práctica del período republicano demuestra que siguió empleándose el procedimiento legislativo en los tratados y convenios que requerían autorización de las Cortes ${ }^{31}$.

Una mutación fundamental se produce en la materia estudiada durante el período 1939-1977. El artículo 14, apartado I, de la Ley Constitutiva de las Cortes, de 1942, disponía lo siguiente:

«La ratificación de tratados o convenios internacionales que afecten a la plena soberanía o a la integridad territorial española serán objeto de ley aprobada por el Pleno de las Cortes.»

De este precepto (reproducido más tarde en el art. 9.a de la Ley Orgánica del Estado de 1967) deben retenerse dos cosas: por un lado, la exigencia expresa de una aprobación por ley y, por otro, su limitación a los tratados que afectasen a la plena soberanía o la integridad territorial española ${ }^{32}$. El ámbito tan circunscrito $\mathrm{y}$ excepcional de esta norma determinó que quedase inédito el procedimiento de autorización por ley en ella previsto.

Fuera de los tratados que afectasen a la plena soberanía o a la integridad territorial, era aplicable el artículo 14, apartado II, de la misma ley, que establecía lo siguiente:

${ }^{30}$ La falta de técnica de esta disposición ya fue manifestada por N. Pérez Serrano, $L a$ Constitución española (9 de diciembre de 1931), Madrid, 1932, pág. 259.

${ }_{31}$ Puede verse, a título ilustrativo, la ley autorizando la ratificación del Convenio entre España y Rumania de 1934. ( «Gaceta de Madrid», 24 de junio de 1934.)

${ }^{32}$ Sobre los problemas de la anterior legislación fundamental, véase Herrero de Miñón, En torno al artículo 14 de la Ley de Cortes, en «Boletín Informativo de Ciencia Política», número 8, 1971; Remiro Bretons, Las Cortes y la política exterior española, Valladolid, 1977, págs. 33 y sigs.; Rodríguez Zapata, Constitución, Tratados internacionales y sistema de fuentes del Derecbo, Bolonia, 1976, págs. 127 y sigs. 
«Las Cortes en Pleno o en Comisión, según los casos, serán oídas para la ratificación de los demás tratados que afecten a materias cuya regulación sea de su competencia, conforme a los artículos 10 y 12.»

Por tanto, cuando las Cortes tenían que intervenir en base a esta disposición no era para conceder o denegar una autorización, sino simplemente para ser oídas. Lo que ejercían, y así lo reconoció la doctrina, era una competencia meramente consultiva. Se limitaban a dar su parecer sobre la conveniencia de que el Estado se obligase por un convenio internacional, parecer que carecía de fuerza vinculante. Precisamente este carácter de dictamen, de simple consulta, hacía inaplicable la forma de ley, pues ésta sólo debe emplearse para acuerdos vinculantes, obligatorios, sean éstos normas generales o actos singulares. Hubiese sido un verdadero contrasentido la aprobación de una ley para expresar una simple opinión no vinculante.

Este artículo 14.II se aplicó a los diversos tratados y convenios internacionales que hubieron de ser conocidos por las Cortes hasta la Constitución de 1978. Ante la ausencia de ley de autorización, todos ellos se insertaban en el Boletín Oficial del Estado a raíz de su ratificación, precedidos sólo por el instrumento correspondiente de ratificación o adhesión.

La aplicación de esta norma durante muchos años ha creado una inercia, y ha hecho aparecer ante muchos ojos como innecesaria la aprobación de una ley, cuando las Cortes intervienen en materia de tratados y convenios internacionales. Tras la instauración del nuevo edificio constitucional ha seguido vigente la práctica administrativa anterior: el Gobierno remite a las Cortes los distintos acuerdos internacionales, sin acompañarlos del proyecto de ley necesario para que puedan dar su autorización, en virtud de lo establecido en el artículo 94.1 de la Constitución ${ }^{33}$. El Congreso de los Diputados y el Senado se ven así muy condicionados sobre la forma de adoptar un acuerdo relativo a un acto que se inicia y se debe al Gobierno. Todo ello explica que la inercia administrativa, y la falta de mayor precisión en el citado artículo 94.1, determinen que los tratados se publiquen en el $B O E$ precedidos simplemente del instrumento de ratificación o adhesión ${ }^{34}$.

La continuación de esta práctica olvida por completo que se ha pasado de un sistema donde las Cortes intervenían a título meramente consultivo a otro donde disponen de la capacidad de autorizar o denegar que el Estado se vincule por un acuerdo internacional. Su decisión tiene ahora carácter vinculante, pues el Gobierno no puede proceder a la ratificación sin la previa autorización de las Cortes. Por eso estimamos que esta autorización -si se quiere que tenga verdadera fuerza de obligar- debe revestir forma de ley. En este sentido, cabe afirmar que los artículos 20 y 29 del Decreto 801/1972 son inaplicables aisladamente tras la entrada en vigor de la Constitución, debiendo integrarse con las exigencias propias del acto de autorización de las Cortes previsto en su artículo 94.1 .

${ }^{33}$ Se ha seguido aplicando el artículo 20 del Decreto $801 / 1972$, de 24 de marzo, que por las razones antedichas no menciona a los proyectos de ley entre los documentos que deben remitirse a las Cortes.

${ }^{34}$ Así lo ordena el artículo 29 del Decreto 801/1972. 


\section{E) Precedentes extranjeros}

Las soluciones del Derecho comparado a esta cuestión son del mismo tenor a la tradicional en España. En Francia, la exigencia de una ley para que el Ejecutivo pudiese vincular al Estado por medio de tratados y convenios internacionales ha sido algo constante. Así, de este modo se interpretó y aplicó el artículo 8 de la Ley constitucional de 16 de julio de 1875 sobre relaciones de los poderes públicos ( «Los tratados de paz, de comercio, los que comprometen las finanzas del Estado... no son definitivos hasta después de haber sido votados por las Cámaras. Ninguna cesión, ningún cambio, ninguna adjudicación de territorio pueden tener lugar más que en virtud de una ley») ${ }^{35}$. El artículo 27 de la Constitución de 1946 disponía que los tratados sólo devienen definitivos después de ratificarse en virtud de una ley.

El artículo 53 de la actual Constitución de 1958 dispone: «Los tratados... no pueden ser aprobados o ratificados sino en virtud de una ley» ${ }^{36}$. Por su parte, el artículo 80 de la vigente Constitución italiana establece: «Las Cámaras autorizarán por ley la ratificación de los tratados internacionales de naturaleza política o que se refieran a arbitrajes o reglamentos judiciales o que impliquen variaciones del territorio, gravámenes en las finanzas o modificaciones de leyes.» En el mismo sentido se manifiesta el artículo 59.2 de la Ley Fundamental de Bonn: «Los tratados que regulen las relaciones políticas de la Federación o se refieran a materias de legislación federal requieren la aprobación o participación, a través de una ley federal, de los respectivos órganos competentes para la legislación federal...» Lo mismo ocurre con el artículo 61 de la Constitución holandesa, que termina con el siguiente párrafo: «En todos los casos en que el tratado es sometido a la decisión de los Estados generales su aprobación no puede ser acordada más que por ley.» En Bélgica, el artículo 68 de su Constitución exige el asentimiento de las Cámaras para determinados tratados. Aunque no se menciona que este asentimiento tenga que hacerse por ley, ésta es la forma aplicada en la práctica ${ }^{37}$. También es la ley el procedimiento empleado en Portugal en virtud de lo ordenado en el artículo 169 de la Constitución en relación con el 164.j.

Por tanto, los Derechos constitucionales de nuestra misma familia jurídica son constantes en exigir la ley para estas autorizaciones parlamentarias. Esta rara coincidencia nos indica que ello no es debido a algo casual, sino que son razones de fondo las que abonan esta solución. Por tanto, para terminar de esclarecer la cuestión conviente estudiar cuáles son estas razones.

${ }^{35}$ En este sentido, véase Carré de Malberg, ob. cit., I, pág. 540.

${ }^{36}$ Sobre esta materia en Francia puede verse Maus, L'Assemblée Nationale et les lois autorisant la ratification des traités, en Revue de Droit Publique et de la Science Politique, 1978, págs. 1075 y sigs.; Saidj, Le Parlement et les traités, L. G.D. J., París, 1979.

${ }_{37}$ Véase Smets, L'assentiment des Cbambres Législatives aux traités internationaux, Bruylant, Bruselas, 1964, págs. 39 y sigs.; del mismo autor, Les traités internationaux devant le Parlement (1945-1955), Bruylant, Bruselas, 1978. 


\section{F) Razones de fondo que aconsejan la forma legislativa para estas autorizaciones de las Cortes}

Ya hemos dicho que dentro de los sistemas políticos de separación de poderes, como el nuestro, el Parlamento tiene en la ley el acto a través del cual puede imponerse sobre todas las autoridades y ciudadanos. Mediante la ley sus acuerdos se hacen vinculantes, obligatorios. En cambio, cuando sus acuerdos no tienen forma legislativa, sino de resolución (entendida ésta en sentido amplio), carecen de esta fuerza de obligar. Las resoluciones parlamentarias son actos de indudable valor político, pero que a efectos jurídicos formales no pasan de simples instrucciones indicativas. Sólo en los casos en que la Constitución prevé un especial efecto para estas resoluciones - caso de la aprobación de una moción de censura, por ejemplo- puede decirse que tienen carácter obligatorio. Ahora bien: esta obligatoriedad se limita al concreto órgano o persona a que van dirigidas. Así, en el ejemplo citado, los efectos de la aprobación de una moción de censura se circunscriben al Gobierno, pero no afectan a otras instancias.

El acto estricto a través del cual el Estado se vincula internacionalmente (ratificación, adhesión, etc.) es de la competencia del poder ejecutivo y se manifiesta formalmente por el Rey (art. 63.2 de la Constitución). En este sentido, si la autorización de las Cortes prevista en el artículo 94.1 se otorga mediante simple resolución, que es lo que ocurre actualmente, el ejecutivo queda legitimado para expedir el correspondiente instrumento para obligar al Estado. En este aspecto, la autorización mediante resolución es irreprochable. Ahora bien: ocurre que esa resolución, en cuantó tal, no tiene relevancia frente a otros poderes u órganos del Estado.

Puestas así las cosas, debe recordarse la competencia de las Cortes para denegar la ratificación, para modificar las propuestas de reservas que el Gobierno pretenda presentar a un tratado, para aprobar otras distintas o para formular propuestas de aplazamiento ${ }^{38}$. El texto del tratado es inmodificable por el Parlamento, pero en cambio las Cámaras sí pueden adoptar estos acuerdos laterales. Imaginemos que, al amparo de estas facultades, las Cortes deniegan su autorización para ratificar un tratado, aprueban una concreta reserva o el aplazamiento de la ratificación. En tales casos, ¿cómo hacer obligatorias de modo general las decisiones de las Cámaras sino por vía de ley? ¿Qué ocurriría si a pesar de la prohibición de las Cortes el Gobierno ratificase un convenio internacional o lo aplicase en modo distinto al acordado por las mismas? Si estos acuerdos revisten la forma de ley es patente la garantía del recurso contencioso-administrativo: el acto de ratificación del Gobierno (acto

${ }^{38}$ Así lo establecen expresamente los artículos 110 del vigente Reglamento del Congreso de los Diputados y 105 del Reglamento del Senado. Para un estudio más extenso sobre este punto nos remitimos a Remiro Brotons, Las reservas a los Tratados internacionales y la competencia de las Cámaras legislativas, en «Revista Española de Derecho Internacional», vol. XXXI, núms. 1-3, 1978-79. Sobre Francia, véase los trabajos de Maud y Saidj, ya citados. 
administrativo) o los de aplicación indebida del tratado podrían ser impugnados por contradecir lo previsto en una ley de Cortes ${ }^{39}$.

Se podría objetar en contra de este aserto que, según el artículo $2 . b$ de la LJCÁ, están exentos del control por la jurisdicción contencioso-administrativa los actos políticos del Gobierno, entre los que figuran los que afecten a las relaciones internacionales. Sin embargo, esta expresión debe entenderse en sus justos términos, como referente a las negociaciones y acciones diplomáticas con otros sujetos del Derecho internacional, pero no puede afectar a un acto administrativo, en cuanto introduce determinadas disposiciones en el Derecho interno español ${ }^{40}$. En este caso no estamos verdaderamente ante un acto diplomático o de relación internacional, sino ante un acto de creación de Derecho interno. Por eso, no pueden aplicarse las exenciones previstas para los actos internacionales; antes al contrario, la importancia de la medida -introducción de una norma de especial resistencia frente a las leyes ${ }^{41}$ - exige que recobren toda su vigencia las garantías frente a los actos del Gobierno y de la Administración.

El artículo 96.1 de la Constitución prescribe que los tratados formarán parte del ordenamiento interno, pero sólo cuando hayan sido válidamente celebrados. No gozan de esta validez y, por tanto, no pasarían al ordenamiento español los tratados, o las disposiciones de los mismos, cuya ratificación hubiese sido efectuada por el Gobierno en contra de lo acordado por las Cortes Generales.

Un supuesto de más fácil realización en la práctica sería que las Cortes aprobasen una reserva a un tratado, que el Gobierno la presentase a la hora de ratificar o adherirse al mismo, pero que, sin embargo, después fuese aplicado el tratado en contravención con esa reserva. Por eso debe establecerse una garantía que permita combatir este acto antijurídico y el aludido en el párrafo anterior, a cuyo efecto no hay medio mejor que el recurso contencioso-administrativo.

Pero, admitida la procedencia de este recurso, debe señalarse cuál sería el motivo de la impugnación. Si el acuerdo de las Cortes tuviese forma legislativa no habría ningún problema: se trataría de impugnar la ilegalidad de un acto gubernativo. En un caso se impugnaría la ratificación por contravenir lo acordado legalmente por las Cortes. En el otro se impugnaría la aplicación de un tratado contrario a una reserva que forma parte de una ley.

Mas, si no tuviese forma de ley, ¿en qué se basaría la impugnación? Desde luego no en la ilegalidad de la medida, pues precisamente es la ausencia de

${ }^{39} \mathrm{El}$ hecho de que, según el artículo 63.2 de la Constitución, es el Rey quien manifiesta el consentimiento del Estado para obligarse mediante tratados, no desmerece lo afirmado, de la misma forma que los actos con forma de Decreto son actos administrativos a pesar de ser firmados por el Jefe del Estado. La atribución al Rey de esta facultad no altera la naturaleza jurídica del acto.

${ }_{40}$ Téngase en cuenta que según el artículo 96.1 de la Constitución Los Tratados válidamente celebrados forman parte del ordenamiento interno, una vez publicados oficialmente en España.

${ }_{41} \mathrm{El}$ mismo artículo 96.1 dispone que las disposiciones de los tratados sólo podrán. ser derogados, modificados o suspendidos en la forma prevista en los propios tratados $o$ en las normas generales del Derecho internacional. 
ley lo que caracteriza esta situación. Se podría suponer entonces que en contradecir un acuerdo o resolución de las Cortes. Pero cadmitiría un Tribunal un recurso contra un acto administrativo basado en contradicción con una resolución parlamentaria? ${ }^{42}$. Ya hemos dicho que las resoluciones de las Cámaras tienen valor político, pero carecen de fuerza de obligar. Formalmente son simples instrucciones indicativas, salvo en los casos específicos en que la Constitución impone ciertos efectos en relación a órganos concretos ${ }^{43}$. En definitiva, estas resoluciones no son derecbo estricto, mientras que el artículo 47 de la LPA proclama la nulidad de los actos que prescindan del procedimiento legalmente establecido, de las disposiciones en los casos previstos en el artículo 28 de la LRJAE (entre las que figuran las disposiciones contrarias a las leyes). El artículo 48 de la LPA declara la anulabilidad de los actos de la Administración que incurran en cualquier infracción del ordenamiento jurídico. Lo mismo establece el artículo 83.2 de la LJCA $^{44}$. El mismo artículo 106.1 de la Constitución proclama que los Tribunales controlan la potestad reglamentaria y la legalidad de la actuación administrativa, así como el sometimiento de ésta a los fines que la justifican. Así, pues, en todos estos casos se manifiesta que el parámetro que permite la impugnación de un acto administrativo es la contravención de una disposición jurídica. Como la resolución parlamentaria no tiene esta naturaleza, no puede servir de base a tales efectos. Con ello se llegaría al resultado de actos de indudable trascendencia que estarían inmunes a todo control efectivo por parte del poder judicial.

\section{G) La forma de ley es una consecuencia del Estado de Derecho}

Por otro lado, la admisión de una actuación semejante en base a una simple resolución parlamentaria supone un claro olvido de uno de los postulados del Estado de Derecho, que, como ha escrito García de Enterría, consiste «en que

${ }^{42}$ Boudet, ob. cit., pág. 279, señala que en Francia tanto los Tribunales como el Consejo de Estado se han negado a controlar las resoluciones parlamentarias. En el mismo sentido, Nocilla ha escrito que «la moción, por su propia naturaleza, no es justiciable, esto es, susceptible de aplícación por parte de los jueces». Véase Mozione, ob. cit., pág. 342.

${ }_{43}$ En el supuesto estudiado esos concretos efectos alcanzan solo al Gobierno, en cuanto que es a él y solo a él a quien se dirige la autorización/prohibición de las Cortes para ratificar. Esto se demuestra en que la autorización no impone la obligación de ratificar. Una vez obtenida aquélla el Gobierno es libre para ratificar o nọ. En este sentido, véase Saidj, ob. cit., y Remiro Bretons, ob. cit.

${ }_{44}$ Como ha escrito García de Enterría (Curso de Derecho Administrativo I, Civitas, Madrid, 1980, págs. 53 y sigs.) la expresión ordenamiento jurídico abarca no sólo las notmas positivas sino también los principios estructurales que dan la unidad de cada ordenamiento. El ordenamiento jurídico contiene como fuentes de Derecho no solo las estatales formalizadas (ley y reglamento), sino también otras distintas: costumbre, jurisprudencia y, especialmente, los ptincipios generales del Derecho. Indudablemente, a pesar de este carácter abierto del ordenamiento jurídico, no parece incluible en el mismo a la resolución parlamentaria ya que ésta, por su parte, no encaja en ninguna de las categorías mencionadas: norma positiva, principios estructurales, costumbre, jurisprudencia, etc. EI mismo autor indica que la expresión «ordenamiento jurídico» del artículo 83 - de la LJCA, se refiere al sistema de fuentes previsto en el artículo 1 del Código Civil. 
toda actuación singular del poder esté justificada en una ley previa» ${ }^{45}$. Como añade el mismo autor, esta exigencia obedece a razones sustantivas: por un lado, «la idea de que la legitimidad del poder procede de la voluntad comunitaria, cuya expresión típica... es la ley, todo el poder es de la ley, toda la autoridad que puede ejercitarse es la propia de la ley»; por otro, viene determinada por el principio técnico de la división de los poderes: «El ejecutivo se designa así porque justamente su misión es 'ejecutar' la ley, ... la distinción entre los poderes legislativo y ejecutivo da al primero la preeminencia y limita al segundo a actuar en el marco previo trazado por las decisiones de aquél, esto es, por las leyes.»

La idea de Estado de Derecho está recogida expresamente en nuestra Constitución. Así, su preámbulo dice:

«La nación española... proclama su voluntad de... consolidar un Estado de Derecho que asegure el imperio de la ley como expresión de la voluntad popular» ${ }^{46}$.

Nótese como, junto a la proclamación del Estado de Derecho, se manifiesta que su finalidad es asegurar el imperio de la ley. Al mismo tiempo se define a la ley como expresión de la voluntad popular. Ahora bien: si esta voluntad popular actúa a través de las Cortes Generales (el art. 66.1 establece que éstas representan al pueblo español), no hay más remedio que concluir que las decisiones de las Cortes Generales deben revestir forma de ley salvo en los contadísimos casos en que la propia Constitución prevé otra forma distinta. Lo cual, por lo demás, es enteramente congruente con los principios jurídicopolíticos que, siguiendo a García de Enterría, hemos expuesto en el párrafo anterior.

Se podría objetar a lo aquí señalado que estas resoluciones tienen fuerza de ley, por proceder de las Cortes Generales y que, de este modo, quedarían eludidos los problemas advertidos en este apartado y en el anterior. Reconociendo valor de ley a estas decisiones de las Cámaras podrían impugnarse ante la jurisdicción contencioso-administrativa las ratificaciones de tratados internacionales hechos por el poder ejecutivo contraviniendo lo acordado por las Cortes. Igualmente, se daría aplicación al principio del Estado de Derecho reconocido en el preámbulo de la Constitución. Sin embargo, esta posible objeción no resulta atendible desde el punto y hora que las leyes no sólo requieren la decisión de las Cortes Generales, sino también la sanción del jefe del Estado (art. 91 de la Constitución) y su publicación en el BOE (art. 2.1 del Código Civil). Ya sabemos que las resoluciones parlamentarias no reciben reciben sanción del Rey ni son objeto de publicación en el diario oficial. Al mismo tiempo, habría que preguntar dónde se establece ese valor de ley en favor de las resoluciones de las Cámaras: una equiparación tan importante, que afecta nada menos que al sistema de fuentes del Derecho, tendría que

45 Véase $o b$. cit., págs. 363 y sigs.

46 En la misma línea el artículo 1.1 de la Constitución dispone que España se constituye en un Estado social y democrático de Derecho. 
estar reconocida expresamente, y, sin embargo, ni la Constitución ni el Código Civil contienen ninguna disposición que directa o indirectamente pueda servir a tales efectos ${ }^{47}$. Y, por otro lado, si hipotéticamente se admitiese el valor de ley de estas resoluciones de las Cortes, cabría preguntar entonces cuál es el inconveniente para que esas autorizaciones se concedan por leyes verdaderas (valga la expresión). Si tienen valor de ley, ¿por qué no utilizar la forma de ley y evitar así toda suerte de problemas interpretativos y otros a los que nos referiremos posteriormente?

\section{H) La forma de ley y la impugnación de los tratados internacionales ante el Tribunal Constitucional}

Es sabido que las normas internacionales se incorporan al Derecho interno mediante el procedimiento y cumpliendo los requisitos que el mismo establece. Desde su propia perspectiva, el Derecho internacional da pleno respeto a lo dispuesto en las normas internas estatales para que las cláusulas de un tratado internacional pasen a formar parte de la legislación interna ${ }^{48}$.

Sobre la base de estas consideraciones, se podría aducir que la contravención de lo dispuesto en la Constitución, para la vigencia interna de los convenios y acuerdos internacionales, determinaría su inconstitucionalidad. $Y$, por tanto, su falta de validez interna: si se obliga al Estado por un tratado, incumpliendo lo acordado por las Cortes, se está vulnerando el requisito establecido en el artículo 94.1 de la Constitución. Así las cosas, podría defenderse que, en defecto de una vía para la impugnación contencioso-administrativa de la ratificación hecha desatendiendo lo acordado por las Cámaras, se podría acudir a otra vía: la de declaración de inconstitucionalidad por el Tribunal Constitucional, al amparo de los artículos 161 de la Constitución y 27.2.c de la Ley Orgánica 2/1979, institutiva de este Tribunal. Con ello existiría una garantía frente a posibles extralimitaciones del ejecutivo en la ratificación de tratados internacionales: en defecto del recurso contencioso-administrativo se podría utilizar el recurso de inconstitucionalidad.

Sin embargo, debe recordarse que el recurso de inconstitucionalidad no es alternativo del recurso contencioso-administrativo.

Así, por un lado, la legitimación activa para interponer este último recurso es mucho más amplia (art. 28 de la LJCA) que la prevista para promover la declaración de inconstitucionalidad. En efecto, según el artículo 29.1 de la Ley Orgánica 2/1979, del Tribunal Constitucional, esta declaración sólo

${ }_{47}$ Esta falta de equiparación no puede achacarse a un meto olvido o falta de precisión técnica del legislador: la utilización de la forma de ley encierra todo un conjunto de garantías para el ciudadano, garantías que están en là base misma del concepto de Estado de Derecho e imperio de la ley.

${ }^{48}$ En este sentido, González Campos ha interpretado la exigencia de publicación interna de los Tratados establecida en el artículo 1.5 del Código Civil: «Si la publicación es requisito esencial para la recepción del Tratado en el orden interno, constituye, al mismo tiempo, una 'condición de aplicación' de las normas convencionales internacionales en el ordenamiento nacional.» Véase Comentarios a las reformas del Código Civil I, Madrid, 1977, pág. 121. 
puede producirse mediante la cuestión de inconstitucionalidad, promovida por jueces o Tribunales, y mediante el recurso de inconstitucionalidad, que aparece reservado por el artículo 32.1 de la misma Ley al presidente del Gobierno, al Defensor del Pueblo, a cincuenta diputados y a cincuenta senadores. Por tanto, la posible garantía que pueda suponer la declaración de inconstitucionalidad es muy reducida si se la compara con la que supondría el recurso contencioso-administrativo: la restricción del número de personas que pueden promover aquélla explica esta diferencia.

Por otro lado, resulta problemática la admisión misma del recurso y de la cuestión de inconstitucionalidad en ciertos casos. Así, si se obligase al Estado por medio de un convenio internacional cuya ratificación no hubiese sido autorizada por las Cortes Generales, parece fuera de duda su posible declaración de inconstitucionalidad por haber incumplido uno de los requisitos procedimentales de la Constitución, en este caso la autorización contemplada en su artículo 94.1. Pero, en cambio, si ocurriese que el Gobierno ratificase un tratado internacional autorizado por las Cortes, pero sin presentar una reserva aprobada por éstas, es muy dudoso que estemos ante un caso de incumplimiento de la Constitución que justifique su declaración de inconstitucionalidad. En efecto, la posibilidad de aprobar reservas y aplaza- . mientos no es algo previsto en la Constitución, sino en los Reglamentos de las Cámaras, por lo que es problemático que su incumplimiento por el Gobierno pueda ser tachado de inconstitucional. Más claramente, si se presentase una reserva aprobada por las Cortes, pero después la aplicación del tratado se efectuase contraviniendo esa reserva, surgiría una infracción, pero no una infracción de rango constitucional. En cambio, si la autorización de las Cortes y las eventuales reservas, declaraciones y aplazamientos aprobados por ellas se incorporasen a una ley, no habría problemas en este sentido, pues la aplicación en contravención de una de estas reservas o declaraciones sería contraria al contenido de una ley y, por ende, susceptible de impugnación contencioso-administrativa.

Pero, hay más todavía en favor de la forma de ley para las autorizaciones de las Cortes. Un tratado o un convenio internacional, en cuanto tales, no pueden ser objeto de normal declaración de inconstitucionalidad ${ }^{49}$. Las normas contenidas en los mismos son especialísimas en cuanto tienen un carácter bifronte: son al mismo tiempo (o pueden serlo) normas de Derecho internacional y normas de Derecho interno. Los tratados internacionales, como ha escrito Rodríguez Zapata, no son normas sólo estatales, sino también internacionales, normas pactadas entre dos o más sujetos de Derecho internacional ${ }^{50}$. Por esta circunstancia, una de las partes de un tratado, en este caso el Estado español, no puede disponer libremente del mismo. Podrá a lo sumo privarle de eficacia en eł Derecho interno, pero ello no impedirá que

49. En los párrafos que siguen nos limitamos a los casos en que el contenido de los Tratadós choquen con las normas constitucionales.

${ }_{s 0}$ Véase Constitución, Tratados internacionales y sistema de fuentes del Derecbo, cit., páginas 289 y sigs.; Miaja de la Muela, Introducción al Derecbo Internacional Público, Madrid, 1974, págs. 125 y sigs. 
ese mismo tratado siga surtiendo efectos, y aun otros nuevos, en el ámbito del Derecho internacional.

Hechas estas precisiones debe recordarse lo que el artículo 39.1 . de la Ley Orgánica 2/1979, del Tribunal Constitucional, establece sobre los efectos de la declaración de inconstitucionalidad. Dice así este precepto:

«Cuando la sentencia declare la inconstitucionalidad declarará igualmente la nulidad de los preceptos impugnados, así como, en su caso, la de aquellos otros de la misma ley, disposición o acto con fuerza de ley a los que deba extenderse por conexión o consecuencia.»

Por tanto, se dispone la nulidad de las disposiciones que resulten inconstitucionales.

Pero, es precisamente la peculiar naturaleza de las disposiciones de un convenio o acuerdo internacional la que impide su declaración de nulidad por el Estado. Este podrá privarlas de vigencia interna cuando contradigan sus normas dispuestas al efecto, pero no podrá declararlas nulas, porque, a pesar de esa contravención, esas normas pueden seguir operando efectos en el ámbito internacional. En efecto, el artículo 27 del Convenio de Viena sobre el Derecho de Tratados, adoptado en Viena el 23 de mayo de 1969 y vigente entre nosotros, establece que «una parte no podrá invocar las disposiciones de su Derecho interno como justificación del incumplimiento de un tratado. Esta norma se entenderá sin perjuicio de lo dispuesto en el artículo $46{ }^{51}$. En el mismo sentido, el artículo 42.1 dispone lo siguiente: «La validez de un tratado o del consentimiento de un Estado en obligarse por un tratado no podrá ser impugnada sino mediante la aplicación de la presente Convención.» Por tanto, este Convenio sobre el Derecho de Tratados prevé el mantenimiento de los efectos de éstos en el plano internacional, independientemente de lo que ocurra en el Derecho interno ${ }^{52}$.

Este mantenimiento de los efectos internacionales de la cláusulas de un tratado impide que se pueda hablar con rigor de su declaración de nulidad por un órgano estatal, cual es el Tribunal Constitucional. Este es un error técnico en que incurre la Ley Orgánica de este Tribunal al establecer la declaración de inconstitucionalidad de los tratados; error técnico padecido sin duda por la omisión en nuestro Derecho de la referencia a la forma legislativa para la autorización de las Cortes Generales y por su inaplicación en la práctica.

${ }^{51}$ El artículo 46 de la Convención de Viena establece lo siguiente:

«1. El hecho de que el consentimiento de un Estado en obligarse por un Tratado haya sido manifestado en violación de una disposición de su derecho interno concerniente a la competencia para celebrar Tratados no podrá ser alegado por dicho Estado como vicio de su consentimiento, a menos que esa violación sea manifiesta y afecte a una norma de importancia fundamental de su Derecho interno.

2. Una violación es manifiesta si resulta objetivamente evidente para cualquier Estado que proceda en la materia conforme a la práctica usual y de buena fe.»

52 Sobre nulidad y terminación de los tratados, véase Díez de Velasco, Instituciones de Derecho Internacional Público I, Madrid, 1978, págs. 135 y sigs. 
El olvido de la necesidad de la ley a estos efectos ha hecho concebir la ilusión de que el tratado, en cuanto tal, es susceptible de impugnación por inconstitucionalidad y de eventual declaración de nulidad (art. 39.1 de la Ley Orgánica 2/1979). En este sentido, ¿podría hablarse con rigor de nulidad de las disposiciones de un tratado multilateral a pesar de la continuidad de su vigencia en el Derecho internacional? Más concretamente, ¿podría hablarse de nulidad como consecuencia de la decisión del Tribunal Constitucional cuando España podría seguir vinculada en el plano internacional por las disposiciones del tratado dado lo previsto en el artículo 42.1 de la Convención de Viena?

En consecuencia, el Estado, en cuanto parte de un tratado, no puede declarar su nulidad. Lo que sí puede hacer es privarle de efectos en el Derecho interno cuando sus disposiciones contradigan la Constitución. Y para ello la utilización de la forma de ley en la autorización de las Cortes cumple un papel fundamental: el Tribunal Constitucional no puede anular un tratado en cuanto tal, pero lo que sí puede hacer es anular el acto estatal que permite que aquél se incorpore a la legislación interna. La Ley de Cortes autorizando al Gobierno para vincular al Estado por un convenio internacional es perfectamente residenciable, como tal ley, ante el Tribunal Constitucional. Anulando esta ley se suprime la base que determina la transformación de las normas internacionales en normas de Derecho interno. El Tribunal Constitucional no anula directamente el tratado internacional. Lo que hace es comprobar si el mismo es conforme o no a la Constitución; si considera que contradice la Constitución, lo lógico es que declare inconstitucional y nula la ley que intenta introducir en el Derecho interno disposiciones no conformes a la misma. De esta forma se consiguen los mismos efectos que si anulase directamente el tratado internacional y se actúa con todo el rigor què exige el Derecho y los principios internacionales. En definitiva, una razón más para revestir con forma de ley las autorizaciones del poder legislativo previstas en el artículo 94.1 de la Constitución.

\section{I) El procedimiento parlamentario y la constancia oficial de la autorización de las Cortes reclaman la forma legislativa}

Por otro lado, la utilización de la forma de ley resuelve los problemas de procedimiento parlamentario, que de otra forma se presentan. Actualmente, y debido a la ausencia de proyecto de ley remitido por el Gobierno, las Cámaras se enfrentan con el problema de determinar el cauce interno por el que deben tramitarse los tratados y convenios internacionales. En la práctica se sigue un procedimiento muy similar al establecido para los proyectos de ley, lo cual es un síntoma claro de la vinculación que existe y debe existir entre tratados y forma de ley. Sin embargo, siempre se plantea el problema de establecer cómo se incorpora a la autorización de las Cortes una eventual reserva o declaración aprobada por las mismas, una modificación de las reservas proyectadas y debidas al Gobierno, un aplazamiento del momento de la ratificación, etc. Si se utiliza, como propugnamos, una ley para la autorización de las 
Cámaras, pueden incorporarse a su contenido estos acuerdos, resolviéndose así el problema de procedimiento ${ }^{53}$.

Junto a lo anterior, deben resaltarse otras consecuencias que se derivarían de la presentación de un proyecto de ley para el trámite de las Cortes previsto en el artículo 94.1 de la Constitución. Sólo así sería aplicable su artículo 89.1, en cuanto otorga prioridad a los proyectos legislativos del Gobierno. Esta norma es consecuencia del hecho de ser el Gobierno el primus movens del sistema parlamentario. Por ello, si se quiere ser congruente con este principio y permitir la aplicación del artículo 89.1 a los tratados y convenios -que sólo el Gobierno puede presentar-, no hay más remedio que tramitarlos acompañados de un proyecto de ley. Asimismo, sólo de esta forma es posible aplicar el artículo 90.2 y 3, en cuanto establece unos plazos de dos meses y veinte días para la intervención del Senado. Es absurdo que esta Cámara esté limitada por estoś plazos en los proyectos de leyes orgánicas para autorizar tratados de transferencia de competencias constitucionales (art. 93) y, en cambio, no lo esté en los tratados y convenios de menor trascendencia jurídica y política.

Una razón más es que sólo la autorización con forma de ley permite dejar constancia de la autorización de las Cámaras. La ley cumple en este sentido un papel de fehacencia del acuerdo de las Cámaras, tanto a efectos internos como internacionales, al serle de aplicación el mandato de publicación inexcusable en el $B O E$ fijado en el artículo 91 de la Constitución ( $« E 1$ Rey sancionará, en el plazo de quince días, las leyes aprobadas por las Cortes Generales y las promulgará y ordenará su inmediata publicación»). Aplicando esta fórmula, todos los ciudadanos y órganos constitucionales pueden comprobar el cumplimiento de lo ordenado en el artículo 94.1. Actualmente, la autorización de las Cortes no se refleja en el $B O E$, sin duda por la dificultad de insertar en éste un acuerdo con mera forma de resolución. Esta autorización sólo se comunica al Gobierno mediante un oficio de los presidentes de las Cámaras. La consecuencia es que los tratados y convenios se publican en el $B O E$ sin más acompañamiento que el instrumento de ratificación, que es un acto del Gobierno. Del acuerdo de las Cortes no queda más que un breve inciso aludiendo a la «aprobación» del tratado por las mismas, contenido en el instrumento de ratificación ${ }^{54}$.

De las consecuencias internas de la falta de forma de ley ya hemos hablado en otros epígrafes. Bástenos ahora unas breves palabras sobre su importancia para las otras partes de un convenio internacional suscrito por España. En efecto, sólo la forma de ley y la consiguiente publicación en el $B O E$ permite constatar el cumplimiento de los requisitos de la legislación interna. Piénsese que, sólo en el caso de violaciones manifiestas de las normas fundamentales del Derecho interno sobre la competencia para celebrar tratados, podrá el Estado interesado alegar vicio de consentimiento, según se dispone, a contrario

\footnotetext{
${ }^{53}$ Así, junto al artículo en que se recogiese la autorización de las Cortes podría añadirse otro recogiendo la reserva o el aplazamiento que se impone al Gobierno.

${ }_{54}$ En este punto debe recordarse que las Cortes no aprueban el Tratado o convenio, sino que autorizan su ratificación.
} 
sensu, en el artículo 46.1 de la Convención de Viena sobre el Derecho de Tratados ${ }^{55}$. El artículo 46.2 de esta Convención aclara lo que se entiende por violación manifiesta: «Una violación es manifiesta si resulta objetivamente evidente para cualquier Estado que proceda en la materia conforme a la práctica usual, de buena fe.» Por consiguiente, para que una violación pueda ser calificada de objetivamente evidente es necesario que se realice contra una disposición de las Cámaras que, con la solemnidad debida, aparezca en el $B O E$, que es el medio a través del cual el Estado se expresa formalmente. En este sentido, no hay forma más idónea que la de la autorización recogida en una ley.

\section{J) La forma de ley no afecta a la entrada en vigor del tratado}

La publicación de la ley de autorización de las Cortes para ratificar un tratado no afecta ni prejuzga el momento de su entrada en vigor. Esta ley debe contener en forma de anexo, o similar, el texto del tratado, pues la autorización por sí sola no tendría sentido. Este acompañamiento tiene como finalidad mostrar que la autorización se refiere a un concreto texto y no a otro, impidiendo así cualquier posibilidad de manipulación. Al formar parte de la ley debe publicarse en el Boletín Oficial del Estado en los términos previstos en el artículo 91 de la Constitución. Sin embargo, ello no condiciona el momento en que el tratado deba cobrar vigencia. Téngase en cuenta que el plazo de vacatio legis previsto en el artículo 2.1 del Código Civil opera, salvo que las disposiciones del tratado dispongan otra cosa, de tal forma que ha de estarse en primer lugar a lo que éste establezca ${ }^{\text {si }}$. Junto a esto también debería publicarse el acto posterior (ratificación, adhesión, canje) por el que el Estado se obliga. En este sentido, el artículo 24 de la Convención de Viena subordina la entrada en vigor de los tratados al cumplimiento de estos actos. Sólo a partir de este momento el Estado queda vinculado internacionalmente y sólo desde entonces pueden cobrar relieve sus cláusulas en el Derecho interno. De ahí la necesidad del anuncio formal de la ratificación, adhesión, etc. ${ }^{5}$.

Por tanto, con lo anterior se demuestra que, desde un punto de vista práctico, nada perjudica que la autorización de las Cortes sea conferida por ley: la entrada en vigor del tratado podrá ser muy distinta a la fecha de su publicación en el diario oficial.

\section{$\mathrm{K})$ Otros argumentos en favor de la forma de ley}

Ya hemos visto que el artículo 93 de la Constitución exige ley orgánica para la autorización parlamentaria de los tratados de transferencia de compe-

${ }_{55}$ Véase el texto de este artículo en nota 51.

${ }^{56}$ En este sentido, González Campos, ob. cit., pág. 119.

${ }^{57}$ Estas publicaciones son ya posibles al amparo de los artículos 31 y 32.3 del repetido Decreto $801 / 1972$, de 24 de marzo. 
tencias constitucionales. Si esto es así para los tratados de mayor trascendencia, parece que lo lógico debe ser emplear ley ordinaria para el resto de los tratados cuya autorización debe conferirse por las Cortes. Entre ambos tipos de tratados no existe diferencia alguna de naturaleza, tanto desde el punto de vista internacional, en cuanto ambos están sujetos a las disposiciones de la Convención de Viena de 1969, como desde el punto de vista del Derecho interno, pues ambos tienen el mismo rango jurídico ${ }^{58} \mathrm{y}$ ambos están sujetos a los mismos requisitos para su incorporación al Derecho estatal, con la excepción de la exigencia de la mayoría absoluta del Congreso de los Diputados (propia de las leyes orgánicas), dado que a ambos son aplicables los artículos 95 y 96 de la Constitución y 1.5 del Código Civil ${ }^{59}$. Por consiguiente, es enteramente posible recurrir al argumento analógico: existe, como dice el artículo 4.1 del Código mencionado, identidad de razón entre ambos supuestos. La lógica de la Constitución no es exigir la ley orgánica en un caso y excluir toda forma legislativa en el otro, sino exigir la primera en cuanto significa la necesidad de que la autorización del Congreso de los Diputados comporte la mayoría absoluta de esta Cámara (art. 81.2 de la Constitución). Para el otro caso (tratados contemplados en el art. 94.1), y a contrario sensu, no se exige más que la regla general de la mayoría simple para adoptar acuerdos (art. 79.2). Por consiguiente, exigida ley orgánica en el primer supuesto, debe exigirse ley ordinaria (aprobada por mayoria simple) en el segundo. No hay razón para requerir forma legislativa en un caso y en otro no.

Por otro lado, nuestro Derecho positivo conoce buen número de casos en que se exige una ley de Cortes para autorizar ciertos actos. Así, por sólo poner unos ejemplos, debe recordarse que, según el artículo 135.1 de la Constitución, «el Gobierno babrá de estar autorizado por ley para.emitir Deuda Pública o contraer crédito»; según el artículo 144.a de la misma, se requiere una ley orgánica para "autorizar la constitución de una comunidad autónoma

ss Sobre la inexistencia de superioridad jerátquica entre leyes orgánicas y leyes ordinarias, véase García de Enterría, Curso..., ob. cit., págs, 133 y sigs.; T. R. Fernández, Las leyes orgánicas y el bloque de la constitucionalidad, Madrid, 1981, págs. 65 y sigs.

${ }^{59} \mathrm{El}$ artículo 1.5 del Código Civil dispone:

«Las normas jurídicas contenidas en los Tratados internacionales no serán de aplicación directa en España en tanto no hayan pasado a formar parte del ordena-. miento interno mediante su publicación íntegra en el Boletín Oficial del Estado.»

El artículo 95 de la Constitución establece lo siguiente:

«1. La celebración de un Tratado internacional que contenga estipulaciones contrarias en la Constitución exigirá la previa revisión constitucional.

2. El Gobierno o cualquiera de las Cámaras puede requerir al Tribunal Constitucional para que declare si existe o no esa contradicción.»

Por su parte, el artículo 96 de la Constitución reza así:

«1. Los Tratados internacionales válidamente celebrados, una vez publicados oficialmente en España, formarán parte del ordenamiento interno. Sus disposiciones sólo podrán ser derogadas, modificadas o suspendidas en la forma prevista en los propios Tratados o de acuerdo con las normas generales del Derecho internacional.

2. Para la denuncia de los Tratados y convenios internacionales se utilizará el mismo procedimiento previsto para su aprobación en el artículo 94.» 
cuando su ámbito territorial no supere el de una provincia»; la aprobación de la Cuenta General del Estado debe hacerse por ley, según se desprende claramente del artículo 136.2 de la Ley 11/1977, de 4 de enero, General Presupuestaria, y así se está aplicando en la práctica; los artículos 26 y 27 de la Ley de Régimen Jurídico de la Administración se refieren a autorizaciones mediante leyes de Cortes; el artículo 61 de la Ley de Patrimonio del Estado exige que la enajenación de bienes inmuebles de más de veinte millones de pesetas se haga por ley. (Esta norma ha debido querer referirse a la autorización por ley, ya que ésta por sí sola no puede determinar la enajenación, como se comprueba en los artículos siguientes de la misma ley.) En definitiva, es patente que en nuestro ordenamiento jurídico se emplea y se exige la forma legislativa para los acuerdos de las Cortes que consistan en autorizaciones y otras decisiones singulares. Por ello, no puede decirse que la autorización legislativa de las Cámaras para ratificar tratados internacionales sería contraria a lo acostumbrado en nuestro Derecho. Al contrario, éste reclama precisamente el empleo de la forma de ley ${ }^{60}$.

Por otro lado, en un régimen de separación de poderes, como en nuestro sistema parlamentario, debe existir en lo posible una diferencia formal entre los actos que provengan del legislativo, del ejecutivo y judicial. Sólo en un régimen de asamblea, con concentración de poderes en un sólo órgano, sería posible que la Cámara o Cámaras adoptasen disposiciones generales, bien en forma de ley o bien con forma de resolución ${ }^{61}$. Esta confusión de poderes en un sólo órgano legitimaría toda disposición vinculante acordada por el mismo cualquiera que fuese su forma. Por el contrario, lo que caracteriza a un sistema de división de poderes es que existen diversos complejos orgánicos, siendo cada uno de ellos, y los propios ciudadanos, autónomos dentro de un ámbito determinado. Concretamente, sólo mediante la ley puede el Parlamento hacer obligatorias, con carácter general, sus decisiones. En este sentido debe recordarse que tradicionalmente el Parlamento ha sido considerado como el poder legislativo del Estado, en razón de que su función primordial es hacer leyes. Los ciudadanos, el ejecutivo y el judicial sólo están sujetos a la ley (excepción hecha de ciertos casos singularísimos de decisiones singulares vinculantes para un concreto órgano). Afirmar lo contrario equivaldría a admitir que el Parlamento podría imponerse a los otros órganos constitucionales y a los ciudadanos con la aprobación de simples resoluciones. Por consiguiente, también los principios estructurales de un sistema de división de poderes, inherente al régimen parlamentario, parecen exigir el empleo del procedimiento legislativo para los acuerdos de las Cortes a los que se pretenda dar fuerza general de obligar.

${ }^{60}$ En el anterior apartado II, D, se recogen una serie de disposiciones de Constituciones históricas españolas, donde se exigían ley de Cortes para diversas autorizaciones al Poder Ejecutivo.

${ }_{61}$ Así, los artículos 53 y siguientes de la Constitución francesa de 1793 preveían que el Cuerpo legislativo pudiese dictar tanto leyes como decretos. 